Jurnal Akuntansi dan Investasi, Vol. 18 No. 1, Hlm: 128-140, Januari 2017

Artikel ini tersedia di website: http://journal.umy.ac.id/index.php/ai

DOI: $10.18196 /$ jai.18165

\title{
Interpretasi Investor Non-Profesional atas Implementasi International Financial Reporting Standard (IFRS) 8 dan Pernyataan Standar Akuntansi Keuangan (PSAK) 5 dalam Perspektif Framing Information
}

Erni Suryandari* \& Imelda Puspita Arisanti

Program Studi Akuntansi Universitas Muhammadiyah Yogyakarta, D. I. Yogyakarta, Indonesia

\begin{tabular}{l}
\hline A R T I C L E I N F O \\
\hline Article history: \\
received 15 Nov 2016 \\
revised 10 Des 2016 \\
accepted 21 Des 2016
\end{tabular}

Keywords:

IFRS 8; PSAK 5;

Framing Effect; Non

Professional Investor's

Interpretation

\begin{abstract}
A B S TRACT
This study aims to examines effects of variable implementation of IFRS 8 which differs in IFRS 8 positive frame, IFRS 8 negative frame, PSAK 5 positive frame, and PSAK 5 negative frame toward non profesional investor's interpretation, in which the report of the segment is different between IFRS 8 and PSAK 5. This study using experiment with factorial design $2 \times 2$ between subject. The subject is 120 participants from accounting undergraduate students of one University in Yogyakarta as a subtitute of non professional investors. Data analysis used to test hypotetical result is multiple regression with additional analysis in the form of case analysis. The results show that segment information in IFRS 8 with positive frame has positive effect on non professional investor's interpretation than those in PSAK 5 with positive frame. In contrast, segment information in PSAK 5 with negative frame does not has effect on non professional investor's interpretation than those in IFRS 8 with negative frame. This study proves that assessment and individu interpretation can be affected by framing and Prospect Theory plays a role in option choosing and the assessment. There is no difference in interpretation by investor non professional when the information given such as difference format.
\end{abstract}

(C) 2017 JAI. All rights reserved

\section{PENDAHULUAN}

Adanya International Financial Reporting Standard (IFRS) memudahkan bisnis terhubung di seluruh dunia dengan standar pelaporan pelaporan keuangan berterima global yang tercermin dalam informasi yang terdapat dalam laporan keuangan. Namun adaptasi IFRS tidaklah mudah. Sebuah negara membutuhkan waktu cukup lama untuk menyesuaikan diri dan memahami karakteristik aturan pelaporan keuangan yang baru. Penerapan IFRS yang efektif mulai berlaku tahun 2012 di Indonesia juga memunculkan banyak kesulitan dan kendala bagi perusahaan terutama dalam banyak aspek seperti aturan mengenai laporan konsolidasian, laporan interim, pengakuan dan pengungkapan imbalan karyawan, segmen operasi, dan sebagainya. Kesulitan yang dialami perusahaan berupa adopsi untuk pertama kali, ketidakjelasan lini jika membedakan kondisi ketika ketentuan akuntansi yang berbeda diterapkan, adanya peningkatan biaya training dan konsultasi terhadap IFRS, atau perusahaan perlu melakukan penyesuaian dalam penyusunan laporan keuangan dengan pengecualian dan larangan yang diberikan IFRS (Putri et al., 2012).

Kesulitan lain juga dirasakan oleh investor. Format laporan konsolidasian yang berubah tentu akan memengaruhi investor dalam memahami isi laporan keuangan secara keseluruhan. Investor perlu belajar dan menyesuaikan diri dengan standar pelaporan ini, sebab banyak informasi yang tentu maknanya berbeda dari standar pelaporan yang sebelumnya. Akan tetapi, permasalahan bukan saja berasal dari pelaporan dan pengungkapan yang berubah saat IFRS telah diterapkan, melainkan juga berasal dari investor itu sendiri. Banyak investor yang tidak bisa memahami dan tidak bisa menafsirkan isi informasi dalam laporan keuangan, baik karena kurangnya pemahaman ekonomi dan investasi maupun karena faktor lainnya. Selain itu, banyak juga investor yang tidak memiliki pengalaman 
yang cukup memadai dalam berinvestasi karena merupakan investor baru (Putri et al., 2012).

Investor yang demikian (baru) disebut sebagai investor non profesional. Investor non profesional akan sulit memahami makna laporan keuangan jika formatnya berbeda dan akan kesulitan menginterpretasi informasi dan memberikan penilaian atas informasi yang termuat di dalamnya, karena ada kemungkinan bukan mereka sendiri yang menafsirkan informasi keuangan, melainkan ada pihak lain yang berperan sebagai penasehat keuangan atau konsultan keuangan yang membantu investor non profesional dalam pengambilan keputusan terkait dengan informasi yang disajikan entitas dalam laporan keuangan. Namun demikian, tetap saja sebagai seorang investor apakah profesional ataupun non profesional seharusnya memahami dan bisa menginterpretasikan informasi dari laporan keuangan yang disajikan (Frederickson dan Miller, 2004).

Terkait dengan adaptasi IFRS dan investor non profesional, salah satu yang mengalami perubahan standar adalah mengenai segmen operasi. Standar IFRS yang mengatur mengenai segmen operasi adalah IFRS 8, sedangkan pada Pernyataan Standar Akuntansi Keuangan (PSAK) yang mengatur tentang pelaporan segmen yaitu PSAK 5. Pelaporan segmen ini bertujuan untuk memberikan informasi pada pengguna mengenai outline pembahasan manajemen yang meliputi kegiatan operasi dan ikhtisar kinerja keuangan segmen. Kedua standar tersebut memiliki perbedaan terkait segmen yang dilaporkan. Perbedaan utama dari dua standar tersebut yaitu; pada IFRS 8 segmen yang dilaporkan adalah segmen operasi saja, sementara pada PSAK 5 melaporkan segmen operasi dengan tambahan rincian per area geografis. Informasi segmen operasi biasanya dapat ditemukan di kolom analisis dan pembahasan manajemen dan merupakan item krusial dalam laporan keuangan karena berisi tinjauan operasi perusahaan selama tahun berjalan (Putri et al., 2012). Oleh karena aturan mengenai segmen operasi di Indonesia berubah secara berkala, yang dimulai dari penerapan PSAK 5 kemudian diubah menjadi penerapan PSAK 5 (revisi 2009), dan sekarang mengadaptasi IFRS 8, maka format penyajian terhadap pelaporan dan pengungkapan segmen secara tidak langsung memengaruhi penafsiran oleh investor non profesional. Format penyajian tersebut berbeda antara perusahaan yang satu dengan yang lainnya tergantung kepada kebijakan masing-masing perusahaan.
Banyaknya segmen operasi dalam pelaporan segmen suatu entitas tentu akan memberikan informasi masing-masing sehubungan dengan pendapatan dan biaya segmen, ukuran profitabilitas segmen, aset dan liabilitas segmen, serta keputusan penting apa yang diambil dan diprioritaskan oleh masing-masing Chief Operating Decision Maker (CODM) di tiap segmen. Komponen kinerja keuangan yang beragam tersebut akan berujung pada laba tiap segmen. Meskipun fokus utama investor adalah laba, tetapi investor juga akan melihat informasi lain yang mendukung terjadinya laba tersebut. Format penyajian dalam pelaporan dan pengungkapan segmen yang disebutkan sebelumnya berpeluang memengaruhi interpretasi laba segmen, terutama bagi investor non profesional dengan membaca dan mempertimbangkan tidak hanya segmen operasi, tetapi tambahan rincian per area geografis.

Nichols et al. (2013) dalam hasil risetnya mengemukakan bahwa pengguna laporan keuangan memandang pengungkapan informasi geografis diperlukan untuk menilai kondisi ekonomi dan politik perusahaan. Konsisten dengan penelititian tersebut, Hope et al. (2009) juga menyatakan bahwa bagi perusahaan yang berhenti mengungkapkan segmen, mengkibatkan penurunan kemampuan investor dalam menggeneralisasi informasi dalam pengumuman laba kuartalan. Interpretasi investor non profesional akan dibayangi oleh perilaku bias dalam pengambilan keputusan investasi, seperti ketidaktahuan informasi; keraguan dalam memberikan penilaian; dan salah persepsi dalam memahami informasi yang disajikan. Seringkali dalam proses pengambilan keputusan banyak para decision maker yang hanya mendasarkan pada cara yang sederhana dan mudah saja (Bazerman, 1994; Hope et al, 2004). Hal tersebut terjadi karena terbatasnya kapasitas kemampuan mereka dalam memproses informasi sehingga mereka hanya mengadopsi cara-cara sederhana dengan menggunakan mental strategies atau heuristics untuk mengatasi kompleksitas masalah yang terjadi (Tversky dan Kahneman, 1974; Elliot dan Jackson, 2006).

Salah satu faktor penyebab munculnya bias adalah framing. Framing ini terkait dengan perbedaan pembingkaian informasi yang disajikan kepada investor, yang diduga berpengaruh terhadap keputusan investor apabila informasi tersebut diframe menjadi informasi yang mengandung gain dan informasi yang mengandung loss. Bias tersebut bisa terjadi pada investor non 
profesional ketika mereka diberikan informasi segmen yang berbeda antara informasi segmen operasi dengan IFRS 8 dengan informasi segmen operasi PSAK yang menambahkan segmen geografis (Arifin, 2004). Peneliti menduga ada perbedaan interpretasi oleh investor non profesional ketika opsi atas penghentian atau pemberlanjutan segmen berdasarkan informasi segmen disajikan dalam bentuk IFRS 8 positive frame, IFRS 8 negative frame, PSAK 5 positive frame, dan PSAK 5 negative frame terkait faktor kesederhanaan atau ketidaksederhanaan format yang kemungkinan memengaruhi keputusan investasi investor non profesional (Arifin, 2004).

Berangkat dari paparan di atas, maka penelitian ini bertujuan untuk menguji secara empiris pengaruh pelaporan segmen operasi dengan IFRS 8 dan PSAK 5 yang dinyatakan dalam positive frame dan negative frame terhadap interpretasi investor non profesional. Penelitian ini memberikan kontribusi pada dampak adopsi IFRS terutama IFRS 8 dan menambah referensi penelitian tentang investor non professional. Kontribusi lain dari penelitian ini adalah menjadi dasar pertimbangan dan penilaian atas informasi segmen agar investor non professional lebih memahami dan handal dalam menginterpretasikan opsi investasi terkait segmen.

\section{TINJAUAN LITERATUR DAN PERUMUSAN HIPOTESIS}

\section{IFRS 8, PSAK 5, dan Interpretasi Investor Non Profesional}

IFRS 8 menetapkan bagaimana sebuah entitas melaporkan informasi segmen operasinya dalam laporan keuangan. Sebagai akibat dari amandemen yang dibuat pada International Accounting Standard (IAS) No. 14, seluruh entitas diwajibkan untuk melaporkan informasi pilihan segmen operasinya dalam laporan keuangan interim, ketika laporan keuangan interim diperlukan. IFRS 8 juga menetapkan persyaratan untuk pengungkapan terkait produk dan jasa, daerah geografis, dan pelanggan penting. Di masa lalu, terdapat perdebatan mengenai nilai dan validitas hasil pengungkapan basis segmen operasi. IFRS 8 mewajibkan entitas untuk melaporkan ukuran laba atau rugi segmen operasi dan aset segmen. IFRS 8 juga mewajibkan entitas pelaporan untuk melaporkan ukuran liabilitas segmen dan pendapatan khusus dan item-item biaya jika ukuran tersebut disediakan rutin oleh Chief Operating Decion Maker, serta mewajibkan rekonsiliasi total pendapatan segmen, total laba atau rugi, total aset, total liabilitas, dan jumlah lainnya yang diungkapakan oleh segmen yang dilaporkan untuk pencocokkan jumlah dalam laporan keuangan entitas (Epstein dan Jermakowicz, 2010). Informasi-informasi tersebut digunakan tidak hanya untuk pelaporan segmen dan untuk penggunaan internal, tetapi juga digunakan dalam laporan keuangan yang diperuntukkan untuk pengguna eksternal untuk menginterpretasikan tinjauan keuangan segmen operasi termasuk sebagai pembanding dengan periode sebelumnya.

\section{Segmen Operasi dan Segmen yang Dilaporkan dalam IFRS 8}

Berbagai standar akuntansi keuangan mendefinisikan segmen operasi dan segmen yang dilaporkan secara berbeda, seperti IAS 14 yang tidak mendefinisikan secara terpisah apa itu segmen operasi melainkan menggabungkannya dalam istilah pelaporan segmen (segmen reporting); sementara PSAK 5 (revisi 2009) dan FAS 131 secara khusus menyatakan bahwa segmen operasi adalah komponen suatu entitas yang (1) menjalankan suatu kegiatan usaha yang dapat menghasilkan pendapatan dan mengeluarkan beban atau biaya; (2) hasil operasinya ditinjau secara berkala oleh chief operating decision maker entitas tersebut untuk membuat keputusan terkait alokasi sumber daya dan mengevaluasi kinerja; dan (3) menyediakan informasi keuangan terpisah dari segmen lainnya.

Menurut Epstein dan Jermakowicz (2010) segmen yang dilaporkan merupakan subset dari segmen operasi. Dengan kata lain, mungkin tidak semua segmen operasi memenuhi kriteria sebagai segmen yang dilaporkan. Kriteria yang ditetapkan IFRS agar suatu segmen operasi memenuhi kualifikasi sebagai segmen yang dilaporkan disebut sebagai ambang batas kuantitatif alternatif (alternative quantitative threshold) dengan angka pengujian sebesar $10 \%$. Segmen operasi yang tidak memenuhi ambang batas kuantitatif tersebut masih dapat dianggap sebagai segmen dilaporkan dan diungkapkan terpisah, apabila menurut manajemen informasi segmen tersebut bermanfaat bagi pengguna eksternal. Oleh karena itu, kunci pemahaman konsep ini adalah penerapan standar IFRS yang tepat, karena tidak setiap bagian dari entitas memerlukan segmen operasi 
atau menjadi segmen operasi itu sendiri, misalnya kantor pusat yang merupakan departemen fungsional dan tidak memperoleh penghasilan.

\section{Karakteristik Pelaporan Segmen PSAK 5}

Pada peristiwa dimana secara internal segmen yang dilaporkan kurang sesuai untuk mendefinisikan segmen industri dan segmen geografis, IFRS 8 mengungkapkan dan melaporkan segmen entitas berdasarkan pada sudut pandang manajemen dan untuk keperluan internal, hal ini tentu berbeda dengan aturan pada PSAK 5. Perbedaan utama pelaporan segmen IFRS 8 dengan pelaporan segmen PSAK 5 adalah bahwa segmen yang dilaporkan hanyalah segmen operasi yang mencakup pembahasan operasi secara umum, pembahasan informasi laba atau rugi segmen, dan pembahasan aset, liabilitas, dan rekonsiliasi total laba rugi segmen, sedangkan pada PSAK 5 perusahaan diharuskan untuk melaporkan segmen operasi, segmen industri, dan segmen geografis dalam pelaporan segmennya.

PSAK 5 menyatakan bahwa untuk tujuan pelaporan, segmen industri dan geografis dapat ditentukan dengan berbagai cara. Pengelompokan aktivitas perusahaan menurut segmen untuk tujuan ini merupakan tanggung jawab manajemen. Dalam keputusannya, manajemen biasanya mempertimbangkan banyak faktor, antara lain kesamaan dan perbedaan produk serta aktivitas perusahaan; profitabilitas, risiko dan pertumbuhan produk serta aktivitas perusahaan; dan bidang-bidang operasi serta pemasaran dan kepentingan relatif masing-masing bidang terhadap perusahaan secara keseluruhan. Adanya ketentuan-ketentuan khusus yang harus dipenuhi dan karakteristik dari industri tertentu seperti industri perbankan dan asuransi merupakan faktor tambahan yang harus dipertimbangkan dalam penentuan segmen yang harus dilaporkan (IAI, 1994). Dalam IFRS, segmen industri dan segmen geografis tidak secara spesifik dilaporkan, sehingga ada kemungkinan bahwa meskipun tidak terkait secara langsung dengan laba, investor non profesional mempertimbangkan segmen industri dan segmen geografis untuk menilai apakah di tahun berjalan segmen atau produk atau segmen yang bersangkutan menguntungkan atau merugikan.

Beberapa penelitian terdahulu mengenai pelaporan segmen menunjukkan bahwa ada ketidakkonsistenan hasil penelitian mengenai perlu tidaknya segmen geografis dan segmen industri dalam pelaporan segmen. Dalam penelitian Hope et al. (2004) berpendapat bahwa ketidakadaan pengungkapan laba segmen geografis tidak berdampak pada keakuratan peramalan analis, sehingga FASB tidak lagi memerlukan pengungkapan laba segmen geografis untuk segmen tambahan dalam memprediksi laba perusahaan multinasional. Senada dengan penelitian tersebut, Chen dan Zhang (2006) berpendapat bahwa perubahan laba antar segmen menyebabkan asimetri informasi terhadap kinerja segmen, yang mengarah pada market misvaluation. Sedangkan Wulandari (2011) menyatakan bahwa pengungkapan segmen geografis sama pentingnya dengan pengungkapan segmen operasi sebab terdapat hubungan positif yang signifikan antara pengungkapan segmen geografis dengan foreign earnings perusahaan. Dari ketiga hasil penelitian tersebut, peneliti menduga bahwa ada tidaknya pengungkapan segmen tambahan seperti segmen geografis selain segmen operasi akan memengaruhi pemahaman dan penilaian laba segmen oleh investor non profesional. Pelaporan segmen berguna untuk mengetahui rincian kegiatan operasi dan kinerja keuangan suatu perusahaan selama tahun berjalan. Dengan melaporkan segmen, hal ini membuktikan bahwa perusahaan transparan dan akuntabel terhadap laporan keuangannya.

Terkait dengan entitas multi segmen, dengan diterapkannya IFRS 8 investor non profesional diduga akan menafsirkan secara berbeda hal-hal yang dilaporkan seperti aset, kewajiban, pendapatan, biaya, dan laba segmen karena format pelaporannya yang berbeda dari aturan sebelumnya, serta penyajian laporan memang ditujukan untuk pelaporan internal dari sudut pandang manajemen justru akan membuat investor non profesional salah menginterpretasi informasi.

Format pelaporan dan pengungkapan segmen disajikan secara berbeda oleh masingmasing perusahaan. Tipikal penyajian tersebut berdasarkan pada kebijakan akuntansi yang diambil perusahaan. Seperti yang telah dibahas sebelumnya bahwa ada perusahaan yang hanya melaporkan segmen operasi sesuai dengan IFRS 8 , ada juga perusahaan yang melaporkan elemenelemen segmen industri dan segmen geografis. Beragam tipikal penyajian pelaporan segmen tersebut sangat memungkinkan memengaruhi penilaian laba secara keseluruhan oleh investor non profesional. Hal itu berkaitan dengan konsep pembingkaian informasi (framing information) yang telah dipaparkan pada bagian sebelumnya. 


\section{Framing Effect pada Implementasi IFRS 8 dan PSAK 5}

Pada umumnya dalam melihat laporan keuangan, investor hanya berfokus pada laba atau rugi sesuai dengan prinsip bottom line. Jika menghasilkan laba, investor akan melanjutkan investasinya dan mengevaluasi secara berkelanjutan, namun jika sebaliknya, maka investor cenderung memilih untuk tidak melanjutkan, atau dari dua kondisi tersebut bisa saja investor bersikap netral, dan investor memiliki kecenderungan untuk memilih alternatif yang memberikan benefit kepadanya.

Framing effect merupakan format atau cara penyampaian informasi yang dibingkai dengan arah tertentu yang dapat memengaruhi individu dalam pengambilan keputusan. Biasanya framing effect ini terjadi pada manajer dan investor. Framing effect pada manajer dalam banyak kasus mengakibatkan timbulnya eskalasi komitmen, sedangkan fenomena framing effect pada investor biasanya menimbulkan konsekuensi terkait dengan keputusan investasi. Di dalam framing effect, informasi disajikan dalam dua jenis pembingkaian, yaitu informasi yang dibingkai positif (positive framed) dan informasi yang dibingkai negatif (negative framed). Informasi yang dibingkai positif merupakan informasi tertentu yang dibingkai dalam bentuk gain/return yang diterima individu, sedangkan informasi negatif merupakan informasi tertentu yang dibingkai dalam bentuk loss/risk yang diterima individu.

Beberapa penelitian mengenai framing effect yang berkaitan dengan pengambilan keputusan telah banyak dilakukan, seperti penelitian Wardani dan Sukirno (2014) yang menyatakan bahwa manajer dalam kondisi positive framing tidak akan berinvestasi dibandingkan pada manajer dalam kondisi tanpa framing, sedangkan manajer dalam kondisi negative framing akan berinvestasi dibandingkan pada manajer dalam kondisi tanpa framing karena informasi yang disajikan dalam negative framing meningkatkan preferensi resiko individu. Konsisten dengan hasil penelitian sebelumnya, Putri et al., (2012) juga menyatakan bahwa partisipan dalam penelitiannya mengambil tindakan yang tidak beresiko ketika informasi disajikan dalam bentuk positive framed. Hasil penelitian tersebut menunjukkan bahwa ketika suatu informasi dibingkai secara positif dan tampak menguntungkan, maka kebanyakan individu akan memilih opsi keputusan yang tidak beresiko dan dapat diterima (acceptable). Namun, framing effect tersebut tergantung pada situasi apakah individu menguraikan atau tidak menguraikan (elaborate) rangkaian informasi selama proses pembuatan keputusan. Dalam kondisi lowelaborate, framing effect dapat diamati namun dalam kondisi high-elaborate, framing effect tidak dapat diamati (Takemura, 1993).

\section{Bingkai Positif (Positifve Frame)}

IFRS 8 menyajikan pelaporan segmen operasi yang melaporkan dan mengungkapkan informasi segmen operasi perusahaan secara keseluruhan. Maksud dari pelaporan dan pengungkapan secara keseluruhan adalah informasi segmen yang tercantum tidak dilaporkan menurut area geografis seperti PSAK 5 tetapi telah secara komprehensif per segmen atau per divisi. Informasi segmen dalam IFRS 8 ini lebih terpadu dan terintergrasi yang menyederhanakan informasi menjadi ikhtisar yang lebih mudah dipahami oleh investor. Bagi investor non profesional kesederhanaan format dan informasi yang "siap pakai" sangat memengaruhi keputusan investasi mereka karena memudahkan mereka dalam melakukan analisis yang berkaitan dengan keputusan investasinya. Eksperimen ini dilakukan karena ada ketidakkonsistenan hasil penelitian seperti penelitian Hope et al. (2009) yang menyatakan bahwa pada perusahaan yang menghentikan pengungkapan laba segmen terdapat penurunan kemampuan investor dalam menggeneralisasi informasi dari pengumuman laba kuartalan.

Oleh karena pengalaman berinvestasi investor non profesional masih kurang, maka mereka masih belum mahir dalam menganalisis laporan keuangan layaknya investor profesional atau analis. Semakin sederhana sebuah informasi, maka semakin banyak yang bisa dipahami oleh investor non profesional. Investor non profesional memproses informasi secara berbeda dengan investor profesional, mereka membaca laporan keuangan dalam urutan penyajian laporan tersebut, sehingga mereka memeroleh informasi yang tidak terstruktur karena mereka belum memiliki model valuasi sendiri (Bouwman, 1982; Maines dan McDaniel, 2000; dalam Fortin dan Berthelot, 2009).

Susanto (2008) dalam Wardani dan Sukirno (2014) menyatakan bahwa pembingkaian informasi berpengaruh terhadap sifat keputusan yang diambil. Putri et al. (2012) menyatakan bahwa partisipan mengambil tindakan yang tidak berisiko 
ketika informasi disajikan dalam bentuk positive framed karena ketika suatu informasi dibingkai secara positif dan tampak menguntungkan, maka kebanyakan individu akan memilih opsi keputusan yang tidak beresiko dan dapat diterima (acceptable). Arifin (2004) juga menyatakan ketika informasi keputusan dapat disederhanakan atau ketika informasi disajikan dalam gain/loss domain positive framing, maka pengaruh framing akan sangat signifikan terhadap pengambilan keputusan dan penilaian partisipan. Berdasarkan uraian tersebut maka hipotesis yang diajukan dalam penelitian ini adalah sebagai berikut:

H1 : Pelaporan segmen operasi dengan IFRS 8 yang dinyatakan dalam positive frame memiliki pengaruh positif yang lebih signifikan terhadap interpretasi investor non profesional dibandingkan pelaporan segmen operasi dengan PSAK 5 yang dinyatakan dalam positive frame.

\section{Bingkai Negatif (Negative Frame)}

IFRS 8 menyajikan pelaporan segmen operasi yang melaporkan dan mengungkapkan informasi segmen operasi perusahaan secara keseluruhan. Maksud dari pelaporan dan pengungkapan secara keseluruhan adalah informasi segmen yang tercantum tidak dilaporkan menurut area geografis seperti PSAK 5 tetapi telah secara komprehensif per segmen atau per divisi. Informasi segmen dalam IFRS 8 ini lebih terpadu dan terintergrasi yang menyederhanakan informasi menjadi ikhtisar yang lebih mudah dipahami oleh investor. Bagi investor non profesional kesederhanaan format dan informasi yang "siap pakai” sangat memengaruhi keputusan investasi mereka karena memudahkan mereka dalam melakukan analisis yang berkaitan dengan keputusan investasinya.

Hal ini karena pengalaman berinvestasi mereka masih kurang sehingga mereka masih belum mahir dalam menganalisis laporan keuangan tidak seperti investor profesional atau analis. Semakin sederhana sebuah informasi, maka semakin banyak yang bisa dipahami oleh investor. Investor non profesional memproses informasi secara berbeda dengan investor profesional, mereka membaca laporan keuangan dalam urutan penyajian laporan tersebut, sehingga mereka memeroleh informasi yang tidak terstruktur karena mereka belum memiliki model valuasi sendiri (Fortin dan Berthelot, 2009). Berbeda dengan Behn et al. (2002) dan Wulandari (2011) yang menyatakan bahwa informasi segmen per negara sangat informatif dan berguna karena lebih mudah diinterpretasikan.

Susanto (2008) dalam Wardani dan Sukirno (2014) menyatakan bahwa pembingkaian informasi berpengaruh terhadap sifat keputusan yang diambil. Arifin (2004) juga menyatakan ketika informasi keputusan tidak dapat disederhanakan atau ketika informasi disajikan dalam gain/loss domain negative framing pengaruh framing tidak signifikan terhadap pengambilan keputusan dan penilaian partisipan. Berdasarkan uraian tersebut maka hipotesis yang diajukan dalam penelitian ini adalah sebagai berikut:

H2: Pelaporan segmen operasi dengan IFRS 8 yang dinyatakan dalam negative frame memiliki pengaruh negatif yang lebih signifikan terhadap interpretasi investor non profesional dibandingkan dengan PSAK 5 yang dinyatakan dalam negative frame.

\section{METODE PENELITIAN}

\section{Desain Penelitian}

Penelitian ini menggunakan metode eksperimen dengan desain faktorial 2x2 between subject. Eksperimen ini memanipulasi suatu kasus dengan framing negatif dan framing positif pada pelaporan hanya segmen operasi dan pelaporan dengan segmen geografis dan segmen industri. Tabel 1 menyajikan desain eksperimen.

Tabel 1. Desain Eksperimen 2x2 Between Subject

\begin{tabular}{ccc}
\hline Format Pelaporan & \multicolumn{2}{c}{ Framing Effect } \\
Segmen Operasi & Positif & Negatif \\
\hline IFRS 8 & A & B \\
Non IFRS 8 (PSAK 5) & C & D \\
\hline
\end{tabular}

\section{Tugas Eksperimen}

Eksperimen dilakukan dalam empat tahapan sebagai berikut: (1) Tahap Pengisian Form Pernyataan Kesediaan dan Data Demografi Partisipan; Tahap ini merupakan tahap awal dimana partisipan diminta untuk mengisi nama dan semester yang sedang ditempuh beserta mengisi beberapa ketentuan persetujuan yang dilanjutkan dengan menandatangani form sebagai tanda kesediaan dan kesepakatan untuk berpartisipasi dalam eksperimen. Setelah itu, partisipan diminta untuk mengisi data demografi yang disediakan untuk keperluan arsip peneliti; (2) Tahap Treatment; Pada tahap ini, partisipan 
diberikan ilustrasi kasus yang terbagi kedalam empat treatment yaitu: ilustrasi kasus dengan format IFRS 8 dalam framing positif; ilustrasi kasus dengan format IFRS 8 dalam framing negatif; ilustrasi tanpa format IFRS 8 (format PSAK 5) dalam framing positif; dan ilustrasi kasus tanpa format IFRS 8 (format PSAK 5) dalam framing negatif. Dalam kasus, partisipan dimanipulasi untuk bertindak seolah-olah sebagai investor yang berinvestasi di PT. KSHS, sebuah perusahaan penghasil kertas. Treatment tersebut diberikan agar partisipan sebagai seorang investor dapat melihat informasi terkait laba perusahaan, berdasarkan informasi tersebut partisipan memutuskan alternatif yang hendak dipilih, apakah alternatif A atau alternatif B; (3) Tahap Pemberian Penilaian atau Interpretasi; Pada tahap ini, setelah diberikan perlakuan, partisipan diminta untuk memberikan penilaian berdasarkan alternatif yang telah dipilih dengan menyatakan apakah alternatif tersebut menguntungkan atau merugikan, dengan tujuan agar peneliti dapat mengetahui apakah partisipan dapat menafsirkan informasi yang diberikan dalam kasus. Opsi tersebut diukur dengan menggunakan skala Diferensial Semantik sesuai dengan persepsi partisipan dengan melingkari angka/poin dari skala; (4) Tahap Manipulation Checki; Pada tahap ini, ada empat soal dalam manipulation check. Partisipan diminta untuk melingkari jawaban benar atau salah $(\mathrm{B} / \mathrm{S})$ pada setiap pernyataan yang tertulis. Manipulation check merupakan kontrol atas jawaban yang diberikan partisipan untuk mengukur besarnya kemampuan partisipan dalam memahami ilustrasi kasus yang diberikan.

Berikut adalah tugas yang harus diselesaikan oleh partisipan berdasarkan treatment yang diberikan: (1) Partisipan yang mendapatkan kasus A diberi treatment kasus dengan IFRS 8 dalam framing positif; (2) Partisipan yang mendapatkan kasus B diberi treatment kasus dengan IFRS 8 dalam framing negatif; (3) Partisipan yang mendapatkan kasus $\mathrm{C}$ diberi treatment kasus dengan PSAK 5 dalam framing positif; dan (4) Partisipan yang mendapatkan kasus D diberi treatment kasus dengan PSAK 5 dalam framing negatif. Semua partisipan yang dibagi ke dalam empat kategori diminta memilih salah satu dari dua alternatif keputusan, yaitu "A" atau "B".

\section{Subjek Eksperimen}

Definisi investor non profesional yang dimaksud dalam penelitian ini adalah investor baru dan calon investor yang kurang berpengalaman dalam bidang investasi serta memiliki background ekonomi tetapi masih belum memahami IFRS secara tepat (Elliot dan Jackson, 2006). Partisipan yang sesuai untuk mewakili investor non profesional merupakan mahasiswa S1, sebab mereka masih dalam proses belajar dan belum berpengalaman dalam berinvestasi meskipun beberapa dari mereka diduga sudah pernah/sedang berinvestasi di komunitas pasar modal dalam rangka mengaplikasikan wawasan yang diperoleh selama proses perkuliahan. Oleh karena itu, subjek penelitian dalam penelitian ini adalah mahasiswa S1 Akuntansi salah satu perguruan tinggi yang ada di Yogyakarta.

Peneliti menggunakan teknik purposive sampling dalam pemilihan partisipan dengan kriteria yaitu mahasiswa S1 Akuntansi yang sedang atau telah mengampu mata kuliah Akuntansi Manajemen, Teori Akuntansi, Pasar Modal \& Teori Portofolio dan Akuntansi Keperilakuan, dikarenakan mahasiswa tersebut diasumsikan memahami keputusan investasi. Partisipan yang diikutsertakan adalah 120 orang dengan masingmasing 30 orang untuk mengisi setiap versi kasus.

\section{Definisi Operasional dan Pengukuran Variabel}

Variabel dependen pada penelitian ini adalah interpretasi investor non profesional yang merujuk pada seberapa jauh pemahaman dan kemampuan investor dalam menafsirkan dan menginterpretasikan informasi segmen perusahaan untuk menilai dan mengambil keputusan terkait keputusan investasinya (Elliot dan Jackson, 2006). Pengukuran variabel interpretasi investor non profesional dilakukan dengan melihat jawaban partisipan dalam skala 1 sampai 7. Skala 1-3 adalah interpretasi merugikan dan skala 4-7 adalah interpretasi menguntungkan.

Sedangkan variabel independen adalah penerapan IFRS 8 dan framing effect. Penerapan IFRS merupakan salah satu aturan yang mengatur pelaporan dan pengungkapan segmen operasi perusahaan oleh manajemen secara internal untuk membuat keputusan (Crawford et al., 2012). Penerapan IFRS 8 adalah standar IFRS yang diterapkan di perusahaan multi-segmen terkait dengan pengungkapan dan pelaporan segmen operasi dalam perusahaan, mulai berlaku di Indonesia sejak Januari 2012. Adapun framing effect didefinisikan sebagai pembingkaian informasi yang dapat memengaruhi decision maker dalam pembuatan 
keputusan. Framing membingkai informasi menjadi informasi yang bersifat gain dan loss yang diduga akan memengaruhi decision maker dalam membuat keputusan.

Framing yang diberikan dalam instrumen kasus diduga dapat memengaruhi interpretasi investor non profesional terhadap opsi keputusan investasi yang diambil baik menghentikan maupun melanjutkan segmen (Putri et al., 2012). Dalam variabel independen ini, partisipan diberi dua opsi alternatif yang mengandung positive dan negative framing: Untuk mengukur variabel ini mengadopsi dari penelitian Yahya dan Surya (2012) dengan beberapa modifikasi yang disesuaikan dengan penelitian ini. Pengukuran variabel ini dilakukan dengan memberikan skor 0 dan 1, perlakuan positive framing akan diberi skor 1 dan perlakuan negative framing akan diberi skor 0 .

\section{Metode Analisis}

Analisis yang digunakan untuk menguji hipotesis dalam penelitian ini adalah analisis regresi linier berganda dengan persamaan sebagai berikut :

\section{PSEG $=\alpha+\beta_{1}$ IFRS $+\beta_{2}$ FRAMING $+\varepsilon$}

Keterangan:

PSEG $=\quad$ interpretasi laba segmen yang diukur dengan menggunakan skala 1-7.

$\alpha=\quad$ adalah konstanta.

IFRS $=\quad$ penerapan IFRS 8 yang meliputi format pelaporan IFRS dan format pelaporan tanpa IFRS dan PSAK 5.

FRAMING $=$ framing effect yang membingkai informasi segmen dalam format IFRS 8 dengan positive dan negative frame dan informasi segmen dalam format PSAK 5 dengan positive dan negative frame. Skor 1 untuk positive framing dan skor 0 untuk negative framing.

$\varepsilon=\quad$ error

\section{Uji Statistik $t$}

Uji statistik $t$ dilakukan untuk mengetahui pengaruh masing-masing variabel independen terhadap variabel dependen.

\section{HASIL DAN PEMBAHASAN}

Statistik deskriptif dari responden (subyek) penelitian disajikan pada Tabel 2 dan 3. Sedangkan hasil uji hipotesis disajikan pada Tabel 4. Berdasarkan hasil uji statistik ditemukan bahwa variabel IFRS 8 positive frame memiliki nilai sig. $t$ $\leq \alpha 0,05$ yaitu $0,002 \leq 0,05$ dan arah koefisien regresi adalah positif artinya IFRS 8 positive frame berpengaruh positif dan signifikan terhadap interpretasi investor non profesional. Untuk variabel PSAK 5 positive frame memiliki nilai sig. $t \leq \alpha 0,05$ yaitu $0,014 \leq 0,05$ dan arah koefisien regresi positif artinya PSAK 5 positive frame berpengaruh positif dan signifikan terhadap interpretasi investor non profesional. Nilai sig $t$ IFRS 8 positive frame $\leq$ nilai sig. $\mathrm{t}$ PSAK 5 positive frame yaitu $0,002 \leq 0,014$ artinya IFRS 8 positive frame berpengaruh positif dan lebih signifikan dibandingkan dengan PSAK 5 positive frame.

Tabel 2. Statistik Deskriptif Status Investasi dari Partisipan

\begin{tabular}{lccc}
\hline \multicolumn{1}{c}{ Keterangan } & Ya & Tidak & Jumlah \\
\hline Status Investasi & 8 & 16 & 24 \\
Kasus A & & & \\
Percent (\%) & 8,33 & 16,67 & 25,00 \\
Status Investasi & 8 & 17 & 25 \\
Kasus B & & & \\
Percent (\%) & 8,33 & 17,71 & 26,04 \\
Status Investasi & 9 & 16 & 25 \\
Kasus C & & & \\
$\begin{array}{l}\text { Percent (\%) } \\
\text { Status Investasi }\end{array}$ & 9,375 & 16,67 & 26,04 \\
Kasus D & 9 & 13 & 22 \\
Percent (\%) & 9,375 & 13,54 & 22,92 \\
\hline Jumlah & 34 & 62 & 96 \\
\hline Percent Total (\%) & $\mathbf{3 5 , 4 1}$ & $\mathbf{6 4 , 5 9}$ & $\mathbf{1 0 0 , 0 0}$ \\
\hline
\end{tabular}

Format laporan segmen IFRS 8 memiliki pengaruh besar terhadap opsi investor dan penilaian atas opsi tersebut, demikian juga informasi dalam segmen dalam PSAK 5. Namun format laporan dalam IFRS 8 menyajikan informasi segmen yang lebih sederhana dan secara komprehensif dibandingkan dengan PSAK 5 yang menyajikan informasi segmen dengan tambahan rincian area geografis. Dengan demikian dapat disimpulkan bahwa $\mathbf{H} 1$ diterima atau terdukung.

Berdasarkan hasil uji statistik ditemukan bahwa variabel IFRS 8 negative frame memiliki nilai sig. $t \leq \alpha 0,05$ yaitu $0,017 \leq 0,05$ dan arah koefisien regresi adalah positif artinya IFRS 8 
Tabel 3. Lama Investasi Partisipan

\begin{tabular}{lcccccc}
\hline \multicolumn{1}{c}{ Keterangan } & Kasus A & Kasus B & Kasus C & Kasus D & Jumlah & Percent (\%) \\
\hline 0 bulan (tidak berinvestasi) & 16 & 17 & 16 & 13 & 62 & 64,58 \\
$\leq 6$ bulan & 3 & 3 & 1 & 5 & 12 & 12,50 \\
6 bulan -1 tahun & - & 2 & 6 & 2 & 10 & 10,42 \\
1 - 3 tahun & 5 & 3 & 2 & 2 & 12 & 12,50 \\
$\geq 5$ tahun & - & - & - & - & - & 0,00 \\
Jumlah & $\mathbf{2 4}$ & $\mathbf{2 5}$ & $\mathbf{2 5}$ & $\mathbf{2 2}$ & $\mathbf{9 6}$ & $\mathbf{1 0 0 , 0 0}$ \\
\hline
\end{tabular}

Tabel 4. Hasil Uji $t$

\begin{tabular}{|c|c|c|c|c|c|c|c|}
\hline \multirow{2}{*}{ Model } & \multicolumn{2}{|c|}{$\begin{array}{c}\text { Unstandardized } \\
\text { Coefficients }\end{array}$} & \multirow{2}{*}{$\begin{array}{c}\text { Standardized } \\
\text { Coefficients }\end{array}$} & \multirow[t]{2}{*}{$\mathrm{t}$} & \multirow{2}{*}{ Sig. } & \multicolumn{2}{|c|}{ Collinearity Statistics } \\
\hline & $\mathrm{B}$ & Std. Error & & & & Tolerance & VIF \\
\hline (Constant) & -.308 & 2.472 & & -.125 & .902 & & \\
\hline IFRS8 Pos Fram & .891 & .247 & .379 & 3.602 & .002 & .946 & 1.057 \\
\hline IFRS8 Neg Fram & .625 & .237 & .279 & 2.634 & .017 & .933 & 1.072 \\
\hline PSAK5 Pos Fram & .651 & .236 & .298 & 2.755 & .014 & .898 & 1.113 \\
\hline PSAK5 Neg Fram & .864 & .188 & .501 & 4.604 & .000 & .887 & 1.128 \\
\hline
\end{tabular}

negative frame berpengaruh positif dan signifikan terhadap interpretasi investor non profesional. Untuk variabel PSAK 5 negative frame memiliki nilai sig. $t \leq \alpha 0,05$ yaitu $0,000 \leq 0,05$ dan arah koefisien regresi positif artinya PSAK 5 negative frame berpengaruh positif dan signifikan terhadap interpretasi investor non profesional. Nilai sig $t$ IFRS 8 negative frame $\geq$ nilai sig $t$ PSAK 5 negative frame yaitu $0,017 \geq 0,000$ yang artinya PSAK 5 negative frame berpengaruh positif dan lebih signifikan dibandingkan dengan IFRS 8 negative frame. Dalam kondisi dimana informasi disajikan dalam negative frame ada kecenderungan dari investor untuk memilih opsi yang menguntungkan bagi mereka. Dari kedua format laporan segmen operasi yaitu IFRS 8 dan PSAK 5 pada negative frame mahasiswa yang memilih opsi menghentikan dan menilai bahwa opsi tersebut menguntungkan sejumlah paling banyak dari pada penilaian lainnya, namun penilaian cenderung beragam ketika informasi disajikan dalam PSAK 5 negative frame dimana partisipan tidak hanya memilih opsi menghentikan tetapi juga memilih opsi melanjutkan dan memiliki penilaian merugikan. Dengan demikian dapat disimpulkan bahwa $\mathbf{H} 2$ ditolak atau tidak terdukung.

\section{Pembahasan}

Berdasarkan hasil analisis dan pembahasan mengenai pengaruh penerapan IFRS 8 dan framing effect terhadap interpretasi investor non profesional, kesimpulan yang dapat diambil adalah hasil pengujian hipotesis 1 dalam pene- litian ini menunjukkan bahwa informasi segmen dalam IFRS 8 dengan positive frame berpengaruh positif dan lebih signifikan terhadap interpretasi investor non profesional dibandingkan informasi segmen dalam PSAK 5 dengan positive frame. Temuan ini menggonfirmasi bahwa peran format laporan segmen IFRS 8 memiliki pengaruh terhadap opsi investor. Dalam kasus penelitian ini, format laporan segmen operasi dalam IFRS 8 menyajikan informasi segmen yang lebih sederhana dan secara komprehensif dibandingkan dengan PSAK 5 yang menyajikan informasi segmen dengan tambahan rincian area geografis, sehingga hal itu memberikan dampak positif pada keputusan investasi dari investor non profesional. Semakin banyak informasi maka semakin kecil yang dipahami oleh investor. Bagi investor non profesional seperti mahasiswa yang belum memiliki banyak pengalaman dalam berinvestasi, kesederhanaan format penyajian informasi sangat memengaruhi mereka dalam proses pemahaman informasi itu sendiri dan framing berperan dalam pembentukan persepsi terhadap pemahaman mereka atas informasi tersebut untuk pengambilan keputusan investasi (Wijayanti dan Rusiti, 2014).

Hasil penelitian ini menunjukkan bahwa kesederhanaan format IFRS 8 dengan positive frame berpengaruh signifikan karena lebih mudah dipahami secara keseluruhan oleh partisipan terhadap interpretasi mereka atas opsi yang dipilih. Hasil penelitian ini konsisten dengan penelitian Arifin (2004) yang menyatakan ketika informasi keputusan dapat disederhanakan atau 
ketika informasi disajikan dalam gain/loss domain positive framing pengaruh framing akan sangat signifikan terhadap pengambilan keputusan partisipan. Format yang sederhana memungkinkan bagi investor non profesional untuk menyerap semua informasi karena keterbatasan yang dimiliki, maka investor non profesional akan menggunakan cara-cara yang sederhana untuk memproses informasi tersebut. Investor non profesional akan lebih mudah memahami konten informasi untuk pengambilan keputusan sehingga penilaian dan interpretasi mereka terhadap keputusan yang diambil berdasarkan informasi yang disajikan akan lebih tinggi, artinya semakin sederhana format pelaporan segmen maka semakin tinggi penilaian dan interpretasi investor non profesional terkait keputusan yang diambil. Dalam kondisi dimana informasi disajikan dalam positive frame, ada kecenderungan dari investor untuk memilih opsi yang menguntungkan bagi mereka.

Hasil penelitian ini konsisten dengan penelitian Putri et al. (2012) yang menyatakan bahwa partisipan mengambil tindakan yang tidak beresiko ketika informasi disajikan dalam bentuk positive framed karena ketika suatu informasi dibingkai secara positif dan tampak menguntungkan, maka kebanyakan individu akan memilih opsi keputusan yang tidak beresiko dan dapat diterima (acceptable). Terkait dengan Teori Prospek, hasil tersebut konsisten dengan penelitian Bateman dan Zeithaml (1989) dalam keadaan informasi disajikan dengan bingkai positif decision maker cenderung akan menghindari resiko dengan mengambil keuntungan yang pasti dari pada menghadapi resiko keuntungan yang tidak pasti dengan tidak melanjutkan proyek. Hal ini mengindikasikan bahwa tidak ada perbedaan interpretasi atas opsi menghentikan segmen diantara kedua format laporan tersebut dalam kondisi positive frame, dan ada pengaruh format laporan segmen dan positive frame lebih besar terjadi kepada mahasiswa yang diberikan kasus dalam IFRS positive frame.

Status investasi juga ternyata mendukung hasil penelitian ini. Hasil penelitian menunjukkan bahwa antara format laporan segmen IFRS 8 dengan positive frame pada mahasiswa yang berinvestasi dengan yang tidak berinvestasi tidak ada perbedaan interpretasi yang menyatakan bahwa opsi menghentikan segmen merupakan menguntungkan. Sebaliknya, justru mean penilaian menguntungkan partisipan yang tidak berinvestasi lebih besar dibandingkan dengan yang berinvestasi. Temuan yang berbeda berlaku pada format laporan segmen PSAK 5 dengan positive frame dimana pada partisipan yang berinvestasi mean penilaian mereka lebih kecil dibandingkan pada partisipan ynag berinvestasi dengan PSAK 5 positive frame.

Pada partisipan yang berinvestasi yang diberikan format laporan segmen IFRS 8 dengan positive frame, ditemukan mean penilaian menguntungkan mereka lebih besar karena kepada mereka yang berinvestasi terbiasa membaca dan menganalisis laporan keuangan saat ini yang sudah terstandar IFRS dan framing memengaruhi mereka. Sedangkan kepada mahasiswa yang diberikan format laporan segmen PSAK 5 mean penilaian menguntungkan mereka lebih kecil, mereka tidak terbiasa dengan laporan keuangan yang terstandar PSAK 5 karena sejak tahun 2012 semua perusahaan go public sudah menggunakan standar IFRS dan framing juga memengaruhi mereka. Temuan tersebut menunjukkan bahwa tidak ada perbedaan interpretasi antara partisipan yang berinvestasi yang diberikan format laporan segmen IFRS 8 dengan format laporan segmen PSAK 5 dengan positive frame.

Sebaliknya kepada mahasiswa yang tidak berinvestasi yang diberikan format laporan segmen PSAK 5 dengan positive frame mean penilaian menguntungkan mereka lebih besar dibandingkan jika diberikan format laporan segmen IFRS 8 dengan positive frame. Hasil ini mendukung hasil penelitian Biyanto (2001) yang menyatakan bahwa pembingkaian informasi memang berpengaruh terhadap sifat keputusan yang diambil, dan pengaruh tersebut akan semakin berkurang seiring dengan bertambahnya pengalaman individual, meskipun pengalaman investasi yang dimiliki partisipan dalam penelitian ini masih kurang sehingga dalam proses memilih opsi dan memberikan penilaian tidak begitu terpengaruh oleh kemungkinan kerugian atau resiko yang akan diterima.

Selanjutnya, hasil pengujian hipotesis 2 dalam penelitian ini menunjukkan bahwa informasi segmen dalam IFRS 8 dengan negative frame dan PSAK 5 dengan negative frame berpengaruh positif terhadap interpretasi investor non profesional. Pelaporan segmen operasi dengan PSAK 5 dalam negative frame berpengaruh positif dan signifikan terhadap interpretasi investor non profesional dibandingkan dengan pelaporan segmen operasi dalam IFRS 8 dengan negative frame. Hasil ini menunjukkan bahwa hipotesis 2 yang diajukan peneliti ditolak. Peran format 
laporan segmen IFRS 8 seharusnya memiliki pengaruh yang lebih besar terhadap pilihan opsi investor dan penilaian atas opsi tersebut karena format laporan segmen operasi dalam IFRS 8 menyajikan informasi segmen yang lebih sederhana dan secara komprehensif dibandingkan dengan PSAK 5 yang menyajikan informasi segmen dengan tambahan rincian area geografis. Namun hasil penelitian eksperimen yang didapatkan berbeda.

Hasil penelitian ini konsisten dengan hasil penelitian Behn et al. (2002) dan Wulandari (2011) yang menyatakan bahwa informasi segmen per negara secara signifikan sangat informatif dan berguna karena lebih mudah diinterpretasikan. PSAK 5 menyajikan segmen geografis dalam pelaporan segmen yang tercantum di laporan keuangan, artinya semakin rinci informasi segmen per negara yang disajikan maka semakin tinggi pula informasi yang dapat diinterpretasikan oleh investor, sebab investor meyakini bahwa informasi seperti itu mencerminkan aktivitas operasi perusahaan atau anak perusahaan selama periode akuntansi yang tersebar tidak hanya di satu wilayah geografis.

Dengan mengetahui informasi segmen per negara, maka investor dapat meninjau tidak hanya aktivitas operasi segmen dalam negeri tetapi juga segmen di negara lain yang akan memberikan gambaran mengenai kajian kinerja perusahaan di masa lalu dan prospek di masa depan yang lebih baik. Pengungkapan segmen geografis memberikan informasi yang lebih baik terkait foreign earnings perusahaan. Dalam kondisi dimana informasi disajikan dalam negative frame, ada kecenderungan dari investor untuk memilih opsi yang menguntungkan bagi mereka.

Hal ini mengindikasikan bahwa tidak ada perbedaan interpretasi atas opsi menghentikan segmen diantara kedua format laporan tersebut dalam kondisi negative frame. Meskipun tidak ada perbedaan, namun pengaruh format laporan segmen dan negative frame lebih besar dan signifikan terjadi kepada mahasiswa yang diberikan kasus dalam PSAK 5 negative frame. Hasil ini menandakan bahwa partisipan mempertimbangkan informasi lain dalam kasus PSAK 5 negative frame. Ternyata ketidaksederhanaan format atau informasi dalam PSAK 5 justru memberikan pertimbangan lain pada partisipan, berbeda dengan hasil penelitian Arifin (2004) yang menyatakan bahwa ketika informasi keputusan tidak dapat disederhanakan atau ketika informasi keputusan disajikan dalam gain/loss domain negative frame pengaruh framing tidak signifikan berpengaruh terhadap pengambilan keputusan partisipan. Rincian informasi segmen per area geografis yang terdapat dalam PSAK 5 akan menambah daftar panjang informasi segmen perusahaan yang harus dianalisis dan membuat informasi tersebut.

Investor non profesional akan mengetahui lebih banyak informasi mengenai segmen per area geografis dibandingkan dengan yang terdapat dalam IFRS 8. Dari informasi-informasi tersebut mereka dapat mempertimbangkan kemungkinan lain dengan matang sebelum mengambil keputusan agar mereka tidak salah langkah terhadap keputusan investasi jangka panjang mereka, sehingga mereka dapat meminimalisir kerugian yang diterima. Bagi investor non profesional yang memiliki keterbatasan pengalaman investasi dengan memanfaatkan banyaknya rincian informasi, mereka dapat memanfaatkan rincian tersebut untuk membuat list atau highlight atau poin-poin penting untuk keperluan analisis. Informasi segmen per area geografis juga dapat menjadi pembanding antara investasi dalam negeri dengan investasi asing (luar negeri). Dengan demikian, semakin banyak informasi segmen per area geografis, maka semakin banyak pula informasi yang dapat dipertimbangkan untuk pengambilan keputusan investasi.

Status investasi juga ternyata mendukung hasil penelitian ini. Hasil penelitian menunjukkan bahwa antara format laporan segmen IFRS 8 dengan negative frame pada mahasiswa yang berinvestasi dengan yang tidak berinvestasi ada perbedaan interpretasi yang menyatakan bahwa opsi menghentikan segmen merupakan menguntungkan, dan mean penilaian menguntungkan partisipan yang tidak berinvestasi lebih kecil dibandingkan dengan yang berinvestasi. Pada partisipan yang berinvestasi yang diberikan format laporan segmen IFRS 8 dengan negative frame, mean penilaian menguntungkan mereka lebih kecil sedangkan kepada mahasiswa yang diberikan format laporan segmen PSAK 5 mean penilaian menguntungkan mereka lebih besar dan framing juga memengaruhi mereka sangat signifikan. Kepada mahasiswa yang tidak berinvestasi yang diberikan format laporan segmen PSAK 5 dengan negative frame, mean penilaian menguntungkan mereka lebih besar dibandingkan jika diberikan format laporan segmen IFRS 8 dengan negative frame. Hasil ini mendukung hasil penelitian Biyanto (2001) yang menyatakan bahwa pembingkaian informasi memang berpengaruh terhadap 
sifat keputusan yang diambil, dan pengaruh tersebut akan semakin berkurang seiring dengan bertambahnya pengalaman individual, meskipun pengalaman investasi yang dimiliki partisipan dalam penelitian ini masih kurang sehingga dalam proses memilih opsi dan memberikan penilaian tidak begitu terpengaruh oleh kemungkinan kerugian atau resiko yang akan diterima.

\section{SIMPULAN}

Penelitian ini bertujuan untuk mengetahui pengaruh variable penerapan IFRS 8 yang dibedakan menjadi IFRS 8 positive frame, IFRS 8 negative frame dan PSAK 5 positive frame, PSAK 5 negative frame terhadap investasi investor non professional. Penelitian ini merupakan penelitian eksperimen dengan desain penelitian factorial $2 \times 2$ between subject. Subjek penelitian merupakan mahasiswa S1 program studi akuntansi Universitas Muhammadiyah Yogyakarta. Hasil penelitian menunjukkan bahwa informasi segmen dalam IFRS 8 dengan positive frame dan PSAK 5 positive frame berpengaruh positif dan signifikan terhadap interpretasi investor non professional, namun informasi segmen dalam IFRS 8 positive frame lebih mudah di interpretasikan oleh investor non professional dari pada informasi segmen dalam PSAK 5 positive frame. Berangkat dari temuan ini maka relevansi adaptasi PSAK 5 menjadi IFRS 8 memberikan dampak positif bagi investor non professional ketika disajikan dalam bentuk positive frame.

Namun demikian, penelitian ini justru menunjukkan bahwa informasi segmen dalam PSAK 5 negative frame dan IFRS 8 negative frame berpengaruh positif dan signifikan terhadap interpretasi investor non professional. Temuan ini tidak sejalan dengan hipotesis yang dirumuskan, yakni diduga berpengaruh negatif terhadap keputusan investor. Alasan yang mungkin menjelaskan temuan ini adalah masih kurang banyaknya pengalaman investor non professional dalam membaca informasi keuangan, sehingga hal itu menjadikan incestor keliru mengambil keputusan investasinya. Penelitian ini juga menemukan bahwa informasi segmen dalam PSAK 5 negative frame lebih mudah diinterprettasikan oleh investor non professional dari pada informasi segmen dalam IFRS 8 negative frame. Artinya, relevansi adaptasi IFRS 8 dari PSAK 5 sekali lagi akan berdampak positif jika disajikan dalam bentuk bukan negative frame, yaitu positive frame.
Keterbatasan dalam penelitian adalah mahasiswa cenderung tidak membaca instruksi pengerjaan kasus secara seksama dan menyeluruh, instrument kasus dalam penelitian ini belum banyak ditemukan serta peneliti tidak menambahkan kuesioner untuk melengkapi konsep akibatnya mahasiswa yang tidak lolos manipulation check cukup banyak. Saran dari penelitian ini penelitian selanjutnya perlu mempertimbangkan siapa yang akan dijadikan subjek penelitian, sebaiknya tidak menggunakan mahasiswa S1 tetapi karyawan. Perbanyak pertanyaan dalam kuesioner dan manipulation check serta upayakan untuk menjadikan instrumen kasus lebih mudah dipahami. Penelitian selanjutnya juga dapat menambah teori seperti teori prospek dan preferensi investor.

\section{DAFTAR PUSTAKA}

Arifin, A. 2004. Pengaruh Framing pada Keputusan Akuntansi Managerial dalam Perspektif Individu-kelompok: Pengujian atas Prospect Theory dan Fuzzy-Trace Theory. Tesis, Universitas Gadjah Mada.

Bateman, T. dan C. Zeithaml. 1989. The Psychological Contest of Strategic Decisions: A Model and Covergent Experiment Findings. Strategic Managment Journal, 10, 59-74.

Behn, B. K., N. B. Nichols, dan D. L. Street. (2002). "The Predictive Ability of Geographic Segment Disclosures by U. S. Companies: SFAS No. 131 vs SFAS No. 14". Journal of International Accounting Research. Vol. 1, 2002, pp 31-44.

Biyanto, F. 2001. Pengaruh Tanggungjawab, Motivasi Intrinsik dan Pembingkaian Informasi Anggaran dalam Pengambilan Keputusan Investasi dengan Group-Shifts sebagai Variabel Pemoderasi. Tesis, Universitas Gadjah Mada.

Chen, P. F. dan G. Zhang. 2006. Segment Profitability, Misvaluation, and Corporate Divestment. HKUST Business School Research Paper No. 07-07. Hong Kong University of Science and Technology Business School.

Crawford, L., C. Helliar dan D. Power. 2012. Politics or Accounting Principle: Why was IFRS 8 so Controvesional?. Publication of 
ICEW Centre of Business Performance. University of Dundee.

Elliot W.B. dan K. E. Jackson. 2006. The Association between Non-professional Investors' Information Choices and Their Portfolio Returns: The Importance of Investing Experience. The Accounting Review.

Epstein, B. J. dan E. K. Jermakowicz. 2010. Interpretation and Application of International Financial reporting Standards. United States of America: Wiley Publishing.

Frederickson, J. R. dan J. S. Miller. 2004. The Effects of Proforma Earnings Disclosures on Analysts' and Nonprofessional Investors' Equity Valuation Judgments. The Accounting Review, 79 (3), 667-686.

Fortin, A. dan S. Berthelot. 2009. Annual Report Risk Disclosures and Non Professional Investor's Judgments and Decisions. Research by Unversity du Quebec a Montreal dan University de Sherbrooke.

Hope, O. K., W. B. Thomas dan G. Winterbotham. 2004. The Impact of Nondisclosure of Geographic Segment Earnings on Earnings Predictability. Journal of Accounting, Auditing \& Finance.

Ikatan Akuntan Indonesia. 1994. Pernyataan Standar Akuntansi Keuangan (PSAK) No. 5 Pelaporan Informasi Keuangan menurut Segmen. Jakarta: Ikatan Akuntan Indonesia.

Nichols, N. B., D. L. Street dan A. Tarca. 2013. The Effect of Segment Reporting under IFRS 8 and SFAS 131 Management Approach: A Research Review". Journal of International Financial Management and Accounting, 24 (3).

Putri, N. K., Z. B. Supriyadi dan E. Nahartyo. 2012. "Experimental Test of Framing and Non-Professional Investor's Decision: Study of Risk Information in IFRS No. 7. Journal of Economics, Business, and Accountancy Ventura, 15 (2), 305-316.

Takemura, K. 1993. Influence of Elaboration on the Framing of Decision. The Journal of Psychology, 128 (1), 33- 39.

Tversky, A. dan D. Kahneman. 1974. Judgment Under Uncertainty: Heuristics and Bias. Science Journal, 185, 1124-131.

Wardani, E. K. dan Sukirno. 2014. Pengaruh Framing Effect terhadap Keputusan Investasi dengan Locus of Control sebagai
Variabel Pemoderasi. Jurnal Nominal, 3 (1).

Wijayanti, G. A. dan C. H. Rusiti. 2014. Analisis Manajemen Laba di Tingkat Segmen Sebelum dan Sesudah Penerapan Adopsi IFRS 8 menjadi PSAK 5 (2009) pada Perusahaan Manufaktur yang Terdaftar di BEI. Jurnal Ekonomi Akuntansi, 1-13.

Wulandari, T. R. 2011. Penerapan Standar Akuntansi Pelaporan dan Pengungkapan Segmen oleh Perusahaan Multinasional. Jurnal Akuntansi dan Pajak, 14 (1).

Yahya, M. N. dan J. Surya. 2012. Pengaruh Framing Effect sebagai Determinan Escalation of Commitment dalam Keputusan Investasi: Dampak dari Working Experience. Jurnal Akuntansi, 4 (2), 153-154. 